\title{
Molecular scanning of candidate mitochondrial tRNA genes in type 2 (non-insulin dependent) diabetes mellitus
}

\author{
A W Thomas, A Edwards, E J Sherratt, A Majid, J Gagg, J C Alcolado
}

\begin{abstract}
Mitochondrial DNA (mtDNA) gene defects may play a role in the development of non-insulin dependent diabetes mellitus (NIDDM). In order to search for potentially diabetogenic mtDNA defects we have applied the technique of single stranded conformational polymorphism (SSCP) analysis to 124 patients with a history of NIDDM and 40 non-diabetic controls. No new heteroplasmic mutations were detected. However, a variety of homoplasmic variants were found in patients with NIDDM; some of these merit further investigation.
\end{abstract}

(f Med Genet 1996;33:253-255)

Key words: diabetes; mitochondrial DNA; MELAS.

An excess of maternal transmission in NIDDM suggests that mtDNA defects might play a role in the disease ${ }^{1}$; several groups have reported the cosegregation of an $A$ to $G$ point mutation at position $3243 \mathrm{bp}$ in the mitochondrial
tRNA $^{\text {leu(UUR) }}$ gene and maternally inherited diabetes/deafness. ${ }^{2}$ This mutation had previously been reported in the syndrome of mitochondrial encephalomyopathy, lactic acidosis, and stroke-like episodes (MELAS). A single pedigree with diabetes and deafness has been found to carry a mtDNA duplication. ${ }^{3}$ In the mitochondrial myopathies, a variety of different mtDNA mutations may result in a similar phenotype and it is our hypothesis that NIDDM may be associated with several mtDNA mutations. Therefore we have applied the molecular scanning technique of SSCP analysis to candidate $\mathrm{mtDNA}$ regions in order to search for potentially diabetogenic mutations. A total of 124 patients with a history of NIDDM were studied. Group A $(n=33)$ consisted of patients with NIDDM and a history of an affected mother. Group B $(n=56)$ represented NIDDM patients with at least one affected sib irrespective of parental diabetes status. Group C consisted of 35 women with previous gestational diabetes. The race matched control group D $(n=40)$ had no
Department of

Medicine,

University Hospital of

Wales,

Heath Park,

Cardiff CF4 4XW, UK

A W Thomas

A Edwards

E J Sherrat

A Majid

J Gagg

J C Alcolado

Correspondence to: Dr Alcolado.

Received 21 August 1995 Revised version accepted for publication 20 November 1995
mtDNA mutations detected in subjects with diabetes and controls

\begin{tabular}{|c|c|c|c|c|c|c|c|}
\hline \multirow[t]{2}{*}{$m t D N A$ region } & \multirow[t]{2}{*}{ Mutation detected } & \multirow[t]{2}{*}{ Position } & \multirow[t]{2}{*}{ Gene } & \multicolumn{4}{|c|}{ Occurrence in subject groups } \\
\hline & & & & $A(n=33)$ & $B(n=56)$ & $C(n=35)$ & $D(n=40)$ \\
\hline $3130-3558$ & $\begin{array}{l}A-G^{h} \\
A-G \\
T-C \\
T-C \\
A-G \\
G-A \\
A-G \\
A-G \\
G-A\end{array}$ & $\begin{array}{l}3243 \\
3348 \\
3394 \\
3396 \\
3434 \\
3438 \\
3447 \\
3480 \\
3483\end{array}$ & $\begin{array}{l}\text { tRNA }^{\text {leu }} \\
\text { ND1 } \\
\text { ND1 } \\
\text { ND1 } \\
\text { ND1 } \\
\text { ND1 } \\
\text { ND1 } \\
\text { ND1 } \\
\text { ND1 }\end{array}$ & $\begin{array}{l}0 \\
1 \\
0 \\
0 \\
0 \\
0 \\
0 \\
0 \\
0\end{array}$ & $\begin{array}{l}1 \\
0 \\
1 \\
1 \\
1 \\
1 \\
2 \\
1 \\
0\end{array}$ & $\begin{array}{l}0 \\
0 \\
0 \\
0 \\
0 \\
0 \\
2 \\
0 \\
0\end{array}$ & $\begin{array}{l}0 \\
0 \\
0 \\
0 \\
0 \\
0 \\
0 \\
1 \\
1\end{array}$ \\
\hline $5454-5920$ & $\begin{array}{l}A-G \\
G-A\end{array}$ & $\begin{array}{l}5656 \\
5780\end{array}$ & $\begin{array}{l}\mathrm{nc}^{\mathrm{a}} \\
\mathrm{tRNA}^{\mathrm{cys}}\end{array}$ & $\begin{array}{l}0 \\
0\end{array}$ & $\begin{array}{l}1 \\
0\end{array}$ & $\begin{array}{l}0 \\
0\end{array}$ & $\begin{array}{l}0 \\
1\end{array}$ \\
\hline $7377-7650$ & $\mathrm{C}-\mathrm{T}$ & 7476 & $\mathrm{tRNA}^{\text {ser }}$ & 0 & 1 & 0 & $2^{*}$ \\
\hline $8196-8445$ & $\begin{array}{l}\text { A-G } \\
\text { G-A } \\
\text { C-T } \\
\text { G-A } \\
\text { 9bp deletion } \\
\text { 9bp repeat } \\
\text { G-A }\end{array}$ & $\begin{array}{l}8245 \\
8251 \\
8252 \\
8269 \\
8277 \\
8277 \\
8290\end{array}$ & $\begin{array}{l}\text { CoII } \\
\text { CoII } \\
\text { CoII } \\
\mathrm{nc}^{\mathrm{b}} \\
\mathrm{nc}^{\mathrm{b}} \\
\mathrm{nc}^{\mathrm{b}} \\
\mathrm{nc} \mathrm{c}^{\mathrm{b}}\end{array}$ & $\begin{array}{l}0 \\
0 \\
0 \\
1 \\
0 \\
0 \\
0\end{array}$ & $\begin{array}{l}1 \\
1 \\
1 \\
1 \\
0 \\
1 \\
1\end{array}$ & $\begin{array}{l}0 \\
0 \\
0 \\
0 \\
0 \\
0 \\
0\end{array}$ & $\begin{array}{l}0 \\
1 \\
0 \\
3 \\
1 \\
0 \\
0\end{array}$ \\
\hline $15788-16150$ & $\begin{array}{l}\text { A-G } \\
\text { G-A } \\
\text { G-A } \\
\mathrm{C}-\mathrm{T} \\
\mathrm{T}-\mathrm{C} \\
\mathrm{C}-\mathrm{T}\end{array}$ & $\begin{array}{l}15924 \\
15927 \\
15928 \\
16069 \\
16093 \\
16126\end{array}$ & $\begin{array}{l}\text { tRNA }{ }^{\mathrm{thr}} \\
\text { tRNA }^{\mathrm{thr}} \\
\text { tRNA }^{\mathrm{thr}} \\
\text { D loop } \\
\text { D loop } \\
\text { D loop }\end{array}$ & $\begin{array}{r}3 \\
1 \\
2 \\
5 \\
19 \\
1\end{array}$ & $\begin{array}{l}\text { nd } \\
1 \\
7 \\
\text { nd } \\
\text { nd } \\
\text { nd }\end{array}$ & $\begin{array}{l}\text { nd } \\
1 \\
6 \\
\text { nd } \\
\text { nd } \\
\text { nd }\end{array}$ & $\begin{array}{c}2 \\
0^{*} \\
7^{*} \\
4 \\
18 \\
0\end{array}$ \\
\hline
\end{tabular}

$\mathrm{nc}^{\mathrm{a}}=$ non-coding $1 \mathrm{bp}$ junction between tRNA ${ }^{\text {asn }}$ and tRNA ${ }^{\text {aln }}$ genes

$\mathrm{nc}^{\mathrm{b}}=$ non-coding intergenic region between CoII and tRNA ${ }^{\mathrm{lys}}$ genes.

* = control group $(n=97)$ screened by PCR/RFLP.

nd $=$ not determined

$\mathrm{h}=$ heteroplasmic

Group A = NIDDM with maternal history.

Group $B=$ NIDDM with affected sibs.

Group $\mathrm{C}=$ gestational diabetes.

Group $\mathrm{D}=$ non-diabetic controls. 


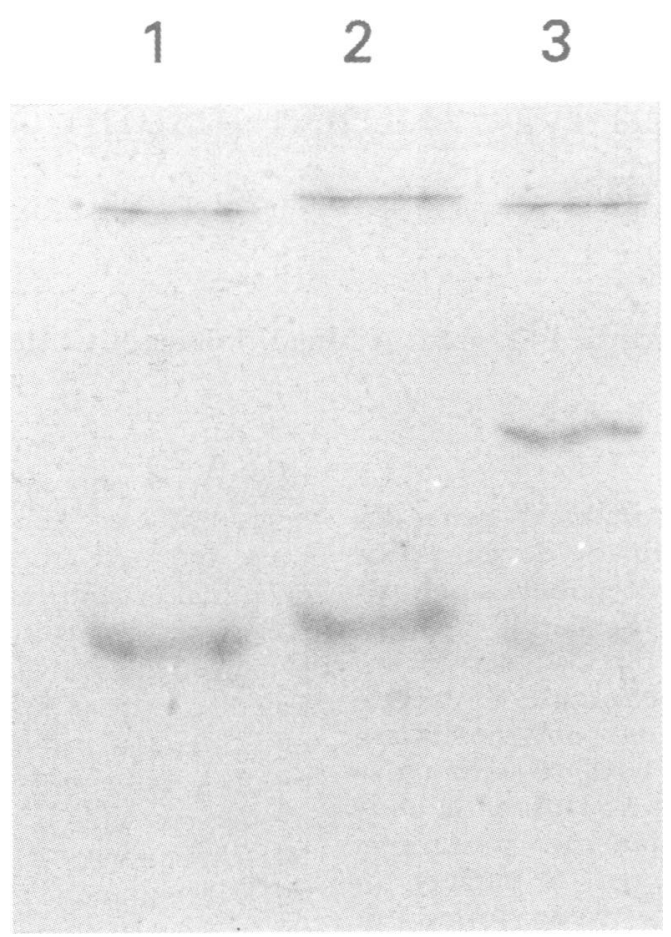

Figure 1 Single stranded conformation polymorphism (SSCP) analysis of the mitochondrial $t R N A^{l y s}$ gene using the Pharmacia Phast System. Lane 1, wild type. Lane 2, 8251 bp homoplasmic mutation (NIDDM patient). Lane 3, 8344 bp heteroplasmic mutation (kind gift from the late Professor A E Harding).

known personal or family history of diabetes. For PCR/RFLP studies, the control group was increased to 97 subjects. No control subject or patient with NIDDM had clinically obvious features of mitochondrial disease, although detailed screening such as audiometry and EMG were not carried out. One pedigree with diabetes and deafness, previously reported to harbour the $3243 \mathrm{bp}$ mtDNA mutation, and one subject without diabetes but with a heteroplasmic mtDNA mutation in the $\mathrm{RNA}^{\text {lys }}$ gene were used as positive controls for heteroplasmic mutations.

Primers were designed to amplify candidate regions of the mitochondrial genome including those where potentially pathogenic mutations have been reported previously (table). SSCP analysis was performed using precast polyacrylamide gels in the PhastSystem (Pharmacia, Uppsala, Sweden), as described elsewhere. ${ }^{4}$ PCR products harbouring SSCPs were purified and then sequenced on an Applied Biosystems Automated DNA Sequencing System (Model 373A). Where a mtDNA variant was found to alter a restriction site (that is, AluI site loss at $7476 \mathrm{bp}$ and MspI site loss at $15927 \mathrm{bp}$ and $15928 \mathrm{bp}$ ), PCR products from all diabetic subjects and a total of 97 controls were genotyped using the appropriate restriction enzyme followed by electrophoresis on ethidium bromide stained gels.

Only two heteroplasmic mutations were detected; these were in the positive control samples. A further 25 homoplasmic mtDNA variants (22 in diabetic subjects) were detected (fig 1, table). Although most of the homoplasmic variants found in NIDDM patients probably represent neutral polymorphisms, a number may merit further attention. These include a $\mathrm{T}$ to $\mathrm{C}$ substitution at $3394 \mathrm{bp}$ which has previously been implicated in Leber's hereditary optic neuropathy (LHON), ${ }^{5}$ and a $9 \mathrm{bp}$ direct triplicate repeat in the intergenic region between CoII and tRNAlys which has been reported in a family with a mitochondrial encephalomyopathy as well as in two other people with symptoms indicative of mitochondrial disease. ${ }^{6}$ The mutation at $5656 \mathrm{bp}$ alters a single nucleotide at the site of mitochondrial transcript scission and further studies will be required to determine whether this might interfere with tRNA processing. The $G$ to $A$ mutation at $15927 \mathrm{bp}$ in the $t \mathrm{NRA}^{\mathrm{thr}}$ was found in $3 / 124$ NIDDM patients but $0 / 97$ controls. This mutation has also been reported in a single
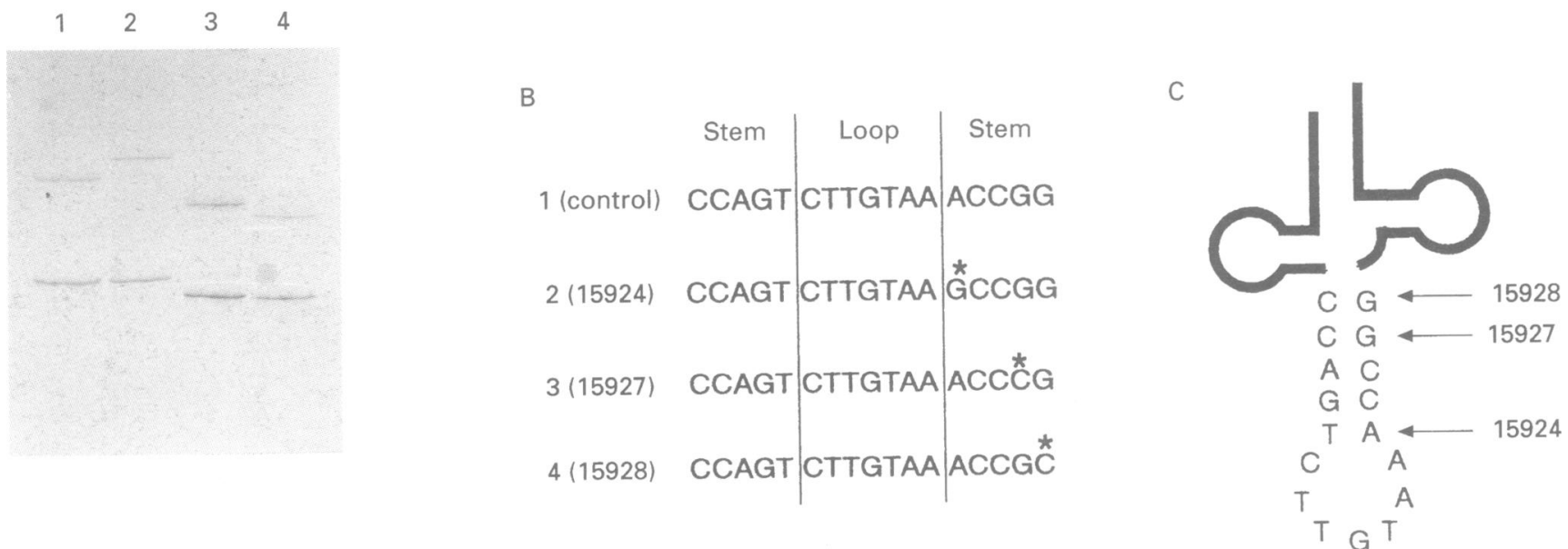

Figure 2 (A) Single stranded conformation (SSCP) analysis of the mitochondrial tRNA $A^{\text {thr }}$ gene. Lane 1 control (wild type), lane $215924 \mathrm{bp}$ mutation, lane 315927 bp mutation, lane 415928 bp mutation. (B) Comparison of normal nucleotide sequence of the anticodon stem and loop regions of the mitochondrial tRNA $A^{\text {thr }}$ gene to mutated sequences. ${ }^{*}=$ mutated mucleotide in each case. (C) Diagram of the mitochondrial tRNA ${ }^{\text {thr }}$ showing molecular position of mutations in the anticodon stem and loop region. 
patient with hypertrophic cardiomyopathy and a second patient with chronic external ophthalmoplegia. ${ }^{7}$ The mutation occurs in the anticodon stem of the tRNA molecule and may adversely effect the tertiary structure required for mRNA binding. Evidence for this structural alteration arises from the large SSCP mobility shifts between the three distinct mtDNA base pair substitutions identified in the tRNA ${ }^{\text {thr }}$ gene (fig 2). We detected a homoplasmic mutation at $7476 \mathrm{bp}$ in one diabetic patient and two controls. This mutation lies close to others reported in patients with maternally inherited deafness. ${ }^{89}$ The significance of this finding is unclear since we did not screen our subjects for deafness.

Review of the clinical notes of patients with NIDDM failed to show any unusual phenotypic characteristics in those subjects with the homoplasmic mtDNA variants discussed above. However, detailed studies (for example, audiometry, echocardiography) will have to be performed in these patients and their relatives in order to define the importance of the mtDNA sequences observed. The results of this study suggest that in patients with NIDDM, heteroplasmic pathogenic mutations are rare within the regions of the mitochondrial genome we have studied. It is still possible that pathogenic mutations are present in other parts of the mitochondrial genome. Further studies are also required to determine whether acquired, somatic mtDNA defects in pancreatic beta cells play a role in the development of the disease.

1 Alcolado JC, Alcolado R. Importance of maternal history of non-insulin dependent diabetic patients. BMF 1991 302: $1178-80$

2 Alcolado JC, Majid A, Brockington M, et al. Mitochondrial gene defects in patients with NIDDM. Diabetologia 1994 37:372-6.

3 Ballinger SW, Shoffner JM, Gebhart S, Koontz DA, Wallace DC. Mitochondrial diabetes revisited. Nature Genet 1994 7:458-9.

4 Thomas AW, Morgan R, Sweeney M, Rees A, Alcolado JC. The detection of mitochondrial DNA mutations using single stranded conformational polymorphism (SSCP) analysis and heteroduplex analysis. Hum Genet 1994;94: 621-3.

5 Brown MD, Voljavec AS, Lott MT, MacDonald I, Wallace DC. Leber's hereditary optic neuropathy: a model for
mitochondrial neurodegenerative diseases. FASEB $\mathcal{1} 1992$; 6:2791-9.

6 Febrizi GM, Tiranti V, Mariotti G, et al. Sequence analysis of mtDNA in a new maternally inherited encephalomyopathy. F Neurol 1992;242:490-6.

7 Hattori Y, Goto Y, Sakuta R, Nonaka I, Mizuno Y, Horai S. Point mutations in mitochondrial tRNA genes: sequence analysis of chronic progressive external ophthalmoplegia (CPEO). I Neurol Sci 1994;125:50-5.

8 Tiranti V, Chariot P, Carella F, et al. Maternally inherited hearing loss, ataxia and myoclonus associated with a nove point mutation in mitochondrial tRNA ${ }^{\text {ser(UCN) }}$ gene. Hum Mol Genet 1995;4:1421-7.

9 Reid FM, Vernham GA, Jacobs HT. A novel mitochondrial point mutation in a maternal pedigree with sensorineural point mutation in a maternal pedigre
deafness. Hum Mutat 1995;3:243-7. 